\title{
Total Syntheses of Cochliomycin B and Zeaenol
}

\author{
Yangguang Gao, ${ }^{[a, b]}$ Jun Liu, ${ }^{[a]}$ Linlin Wang, ${ }^{[a]}$ Ming Xiao, ${ }^{[a]}$ and Yuguo Du*[a,b]
}

Keywords: Natural products / Total synthesis / Lactones / Coupling reactions / Metathesis

Divergent syntheses of two 14-membered resorcylic acid lactones (RALs), cochliomycin B (6) and zeaenol (22), have been accomplished. The key feature in our strategy was the facile construction of three contiguous stereogenic centers in the title molecules by using natural L-arabinose as the chiral template. The key reactions included Takai olefination, Suzuki cross coupling, transesterification, and a late-stage ringclosing metathesis (RCM).

\section{Introduction}

Microorganisms have proved to be rich sources of bioactive secondary metabolites, and therefrom numerous compounds with potent biological activities and unique chemical structures have been discovered. Sharing the common core structural characteristics, $\beta$-resorcylic acid lactones (RALs) have been known for decades since the first isolation of radicicol (1, Figure 1$)^{[1]}$ followed by zearalenone, ${ }^{[2]}$ (5Z)-7-oxozeaenol (3, or LL-Z1640-2), ${ }^{[3]}$ and hypothemycin (4) ${ }^{[4]}$ Interestingly, the original chemical structures proposed for radicicol and hypothemycin were mistakenly assigned, and even the original bioactivities of RALs did not solicit much interest from the bioorganic chemistry community, except for zearalenone, which was shown to have estrogen agonistic properties. From the early 1990s, especially after the discovery of the inhibitory activity of radicicol against HSP90, ${ }^{[5]}$ RALs have undergone extensive bioactivity screening and revealed powerful biological activities with respect to antifungal, ${ }^{[6]}$ antimalarial, ${ }^{[7]}$ antiviral, and cytotoxic effects. ${ }^{[7,8]}$ Furthermore, several members of this natural product family have been reported to be potent kinase and ATPase inhibitors. ${ }^{\left[{ }^{3]}\right.}$ For example, aigialomycin D (2; Figure 1) shows cytotoxicity in human cells through CDK/GSK-3 inhibition, ${ }^{[10]}(5 Z)-7$-oxozeaenol (3) is an inhibitor of TAK-1, ${ }^{[11]}$ and hypothemycin (4) has been reported to inhibit the ras signaling pathway. ${ }^{[12]}$ Surprisingly, structurally similar radicicol and pochonin $\mathrm{C}^{[13]}$ do not inhibit specific kinase, but rather the specific ATPase (HSP90)

[a] State Key Laborotary of Environmental Chemistry and EcoToxicology, Research Center for Eco-Environmental Sciences, Chinese Academy of Sciences,

Beijing 100085, China

E-mail: duyuguo@rcees.ac.cn

http://www.rcees.cas.cn/yjsjy/bssdsjj/201007/t20100713 2901983.html

[b] School of Chemistry and Chemical Engineering, University of Chinese Academy of Sciences,

Beijing 100049, China

$\square$ Supporting information for this article is available on the WWW under http://dx.doi.org/10.1002/ejoc.201301613. and HSV-helicase, respectively. Compounds $\mathbf{1}$ and $\mathbf{3}$, on the other hand, have been shown to be competitive ligands for the ATP-binding pocket. ${ }^{[14,15]}$ radicicol (1)

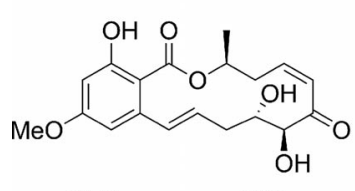

5Z-7-oxozeaenol (3)<smiles>C[C@H](CO)C[C@H](O)/C=C\C=C/C(=O)Cc1cc(O)cc(O)c1C(=O)O</smiles><smiles>CC(O)C/C=C/C(O)C(O)CC/C=C/c1cc(O)cc(O)c1C(=O)O</smiles>

aigialomycin $\mathrm{D}(\mathbf{2})$

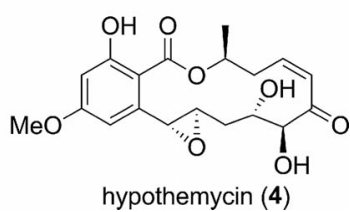

Figure 1. Typical RALs.

In 2011, Wang and co-workers ${ }^{[16]}$ reported the isolation and structural determination of potent antifouling RALs from the culture broth of the fungus Cochliobolus lunatus from the South China Sea. Among the species showing antibacterial and cytotoxic activities, two new 14-membered resorcylic acid lactones with a rare natural acetonide group and one new 5-chloro-substituted lactone were discovered and named as cochliomycins A-C (5-7, respectively, in Figure 2),. Very recently, Nanda and co-workers completed the total synthesis of cochliomycin A (5) ${ }^{[17]}$ and $5^{\prime}$-epi-cochliomycin $\mathrm{C}^{[18]}$ taking advantage of Julia olefination in their strategy. A literature search revealed that numerous total syntheses of RALs have been reported, ${ }^{[19]}$ but to the best of our knowledge no synthesis of cochliomycin B (6) has been presented so far. The high potential of finding new ATPase or kinase inhibitors from this class of species has encouraged us to design a modular diversity-oriented synthesis amenable to the preparation of libraries extending beyond the naturally available compounds. In this work cochliomycin B and zeaenol were used as targets to explore a practical approach towards our goal. 


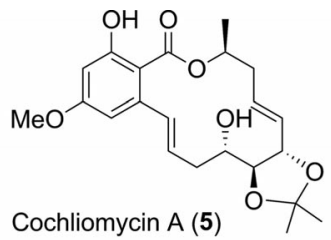<smiles>C/C=C/C(O)C1OC(C)(C)OC1C/C=C\CCC(C)OC(=O)c1c(O)cc(OC)cc1O</smiles>

Cochliomycin B (6)

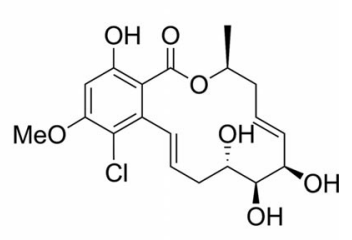

Cochliomycin C (7)

Figure 2. Structures of cochliomycins A-C.

\section{Results and Discussion}

The structure of cochliomycin B (6) consists of a resorcinol moiety fused to a 14-membered macrocyclic lactone ring that includes one methyl group, two trans double bonds, and three adjacent hydroxy groups. The retrosynthetic strategy to $\mathbf{6}$ is delineated in Scheme 1. Cochliomy-<smiles>C=CCC(C)OC(=O)c1c(O)cc(OC)cc1C=CCC1OC2(C)OC(O)C1O2</smiles>
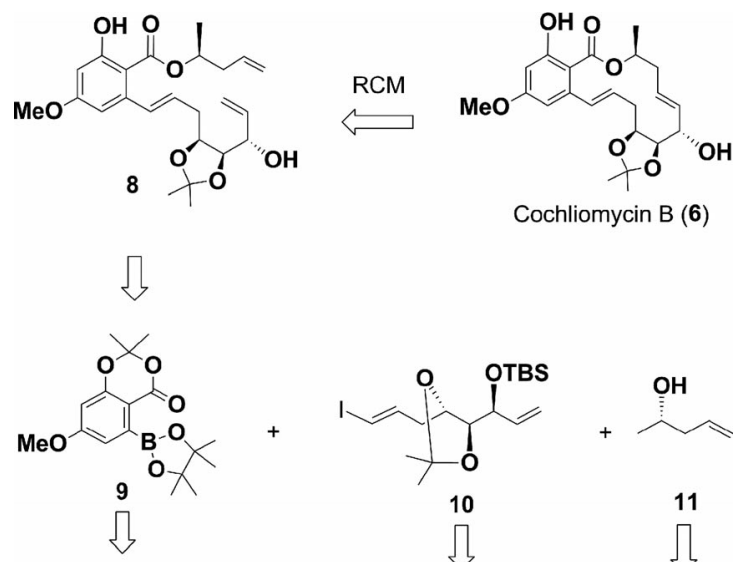
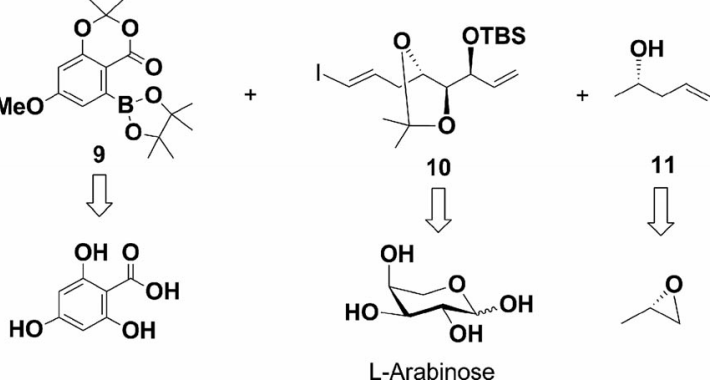

Scheme 1. Retrosynthetic analyses of cochliomycin B. cin B (6) could be obtained from the advanced triene 8 through ring-closing metathesis (RCM), with 8 being constructed from arylborane 9, vinyl iodide intermediate $\mathbf{1 0}$, and $(S)$-pent-4-en-2-ol (11) successively by Suzuki crosscoupling and alkoxide-mediated transesterification. Note that the key intermediate vinyl iodide 10, which contains three contiguous hydroxy groups, could be prepared from readily available L-arabinose with three inherent chiral centers.

Fragments 9 and 11 are both known compounds. Fragment 9 was prepared from commercially available 2,4,6trihydroxybenzoic acid over four steps according to a literature procedure ${ }^{[20]}$ and fragment $\mathbf{1 1}$ was derived from the coupling reaction of $(S)$-propylene epoxide and vinylmagnesium bromide in the presence of catalytic $\mathrm{CuI}$ in dry THF. ${ }^{[21]}$ The key intermediate for the whole target assembly, fragment 10, was synthesized starting from natural L-arabinose in eight steps (Scheme 2). Thus, treatment of L-arabinose with 2,2-dimethoxypropane (DMOP) in dry $N, N^{\prime}$-dimethylformamide (DMF) in the presence of a catalytic amount of $p$-toluenesulfonic acid (PTSA) afforded 3,4$O$-isopropylidene-L-arabinopyranose in high yield. ${ }^{[22]}$ Wittig reaction of this sugar hemiacetal intermediate with (methyl)triphenylphosphonium bromide in dry THF with $n \mathrm{BuLi}$ as the base afforded diol compound 12. Selective blocking of the secondary hydroxy group of $\mathbf{1 2}$ was accomplished in two sequential steps, that is, full protection of 12 with $\mathrm{TBSCl}$ and imidazole in $\mathrm{CH}_{2} \mathrm{Cl}_{2}(\rightarrow 13$, yield $95 \%$ ) followed by selective removal of the primary silyl ether in the presence of catalytic pyridinium $p$-toluenesulfonate (PPTS) in 95\% ethanolic solution provided primary alcohol 14 in $81 \%$ yield. ${ }^{[23]}$ Dess-Martin oxidation of the primary alcohol in 14 generated aldehyde 15, which was subjected to homologation with (methoxymethyl)triphenylphosphorane in the presence of $t \mathrm{BuOK}$ to afford methyl enol ether 16 in $77 \%$ yield. ${ }^{[24]}$ To our surprise, the subsequent hydrolysis of $\mathbf{1 6}$ with mercury acetate under previously reported reaction conditions ${ }^{[25]}$ provided an unexpected elimination product ( $\alpha, \beta$-unsaturated aldehyde). By using a modified procedure, ${ }^{[26]}$ we were pleased to find that treatment of the methyl enol ether $\mathbf{1 6}$ with mercury acetate at $0{ }^{\circ} \mathrm{C}$ in $\mathrm{THF} / \mathrm{H}_{2} \mathrm{O}(\mathrm{v} / \mathrm{v}, 4: 1)$ followed by the addition of $8 \%$ KI solution gave aldehyde $\mathbf{1 7}$ in $75 \%$ yield. Takai ole-

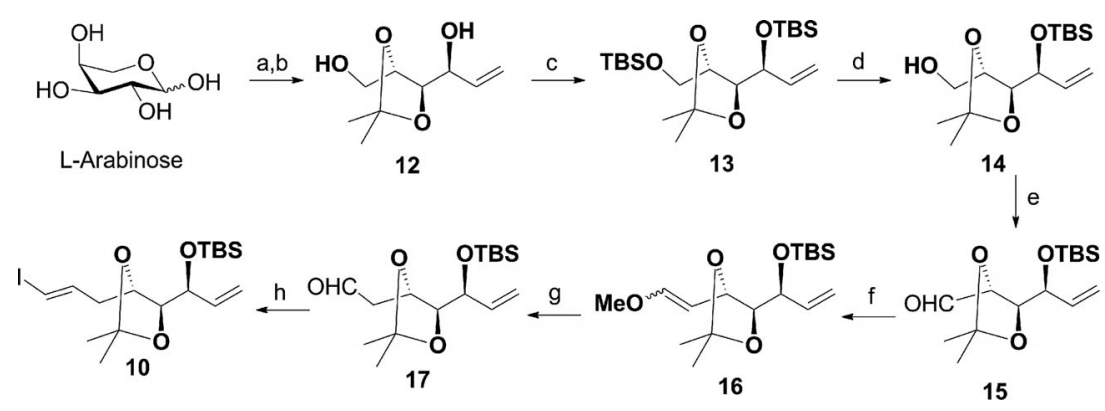

Scheme 2. Synthesis of fragment 10. Reagents and conditions: a) DMOP, PTSA, DMF, 91\%; b) $\mathrm{Ph}_{3} \mathrm{PCH}_{3} \mathrm{Br}, n \mathrm{BuLi}$, THF, $0{ }^{\circ} \mathrm{C}$ to room temp., $72 \%$; c) TBSCl, imidazole, $\mathrm{CH}_{2} \mathrm{Cl}_{2}, 95 \%$; d) PPTS, $95 \%$ EtOH, $81 \%$; e) Dess-Martin periodinane, $\mathrm{NaHCO}_{3}, \mathrm{CH}_{2} \mathrm{Cl}_{2}, 86 \%$; f) $\mathrm{Ph}_{3} \mathrm{PCH}_{2} \mathrm{OMeCl}, t \mathrm{BuOK}, \mathrm{THF}, 0{ }^{\circ} \mathrm{C}$ to room temp., $77 \%$; g) $\mathrm{Hg}(\mathrm{OAc})_{2}, \mathrm{THF} / \mathrm{H}_{2} \mathrm{O}(\mathrm{v} / \mathrm{v}, 4: 1), 0{ }^{\circ} \mathrm{C}$, then $8 \% \mathrm{KI}, 75 \%$; $) \mathrm{CrCl}_{2}, \mathrm{CHI}_{3}$, THF, $0{ }^{\circ} \mathrm{C}, 65 \%(E / Z=4.5: 1)$. 

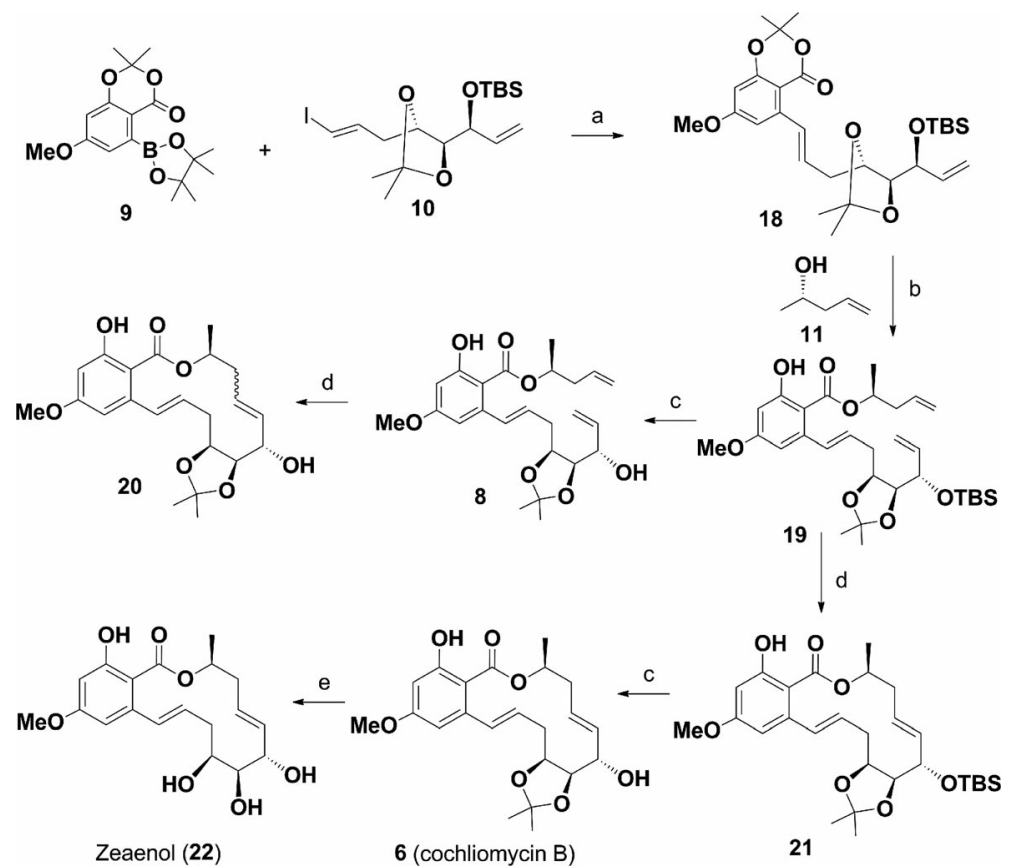

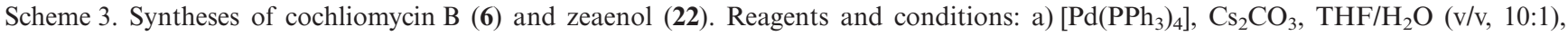
$70{ }^{\circ} \mathrm{C}, 68 \%$; b) 11, NaH $\left(60 \%\right.$ in mineral oil), THF, $0{ }^{\circ} \mathrm{C}, 75 \%$; c) TBAF, THF, $82 \%$ for 8; $85 \%$ for 6 ; d d Grubbs II catalyst, $\mathrm{CH}_{2} \mathrm{Cl}_{2}$, $40{ }^{\circ} \mathrm{C}, 67 \%$ for 21 ; $42.5 \%$ for 20 ; e) $\mathrm{AcCl}, \mathrm{MeOH}, 91 \%$.

fination ${ }^{[27]}$ of the resulting 17 with $\mathrm{CrCl}_{2}$ and $\mathrm{CHI}_{3}$ in dry THF at $0{ }^{\circ} \mathrm{C}$ was carried out smoothly to furnish transvinyl iodide fragment $\mathbf{1 0}$, albeit with a minor amount of the cis-vinyl iodide $(65 \%, E / Z=4.5: 1, J=14.4 \mathrm{~Hz}$ for $E ; J=$ $7.6 \mathrm{~Hz}$ for $Z$ ).

With all the required fragments in hand, we then focused our attention on the total synthesis of cochliomycin B (6) following the retrosynthetic analysis shown in Scheme 1. Accordingly, Suzuki cross-coupling of arylborane 9 and vinyl iodide 10 was investigated (Scheme 3) in $\mathrm{THF} / \mathrm{H}_{2} \mathrm{O}$ $(10: 1)$ at $70{ }^{\circ} \mathrm{C}$ in the presence of a catalytic amount of $\left[\mathrm{Pd}\left(\mathrm{PPh}_{3}\right)_{4}\right]$ and 4 equiv. of $\mathrm{Cs}_{2} \mathrm{CO}_{3}$, affording compound 18 readily in a yield of $68 \% .{ }^{[20 c]}$ The esterification of compound 18 and fragment $\mathbf{1 1}$ was initially explored in two conventional steps, that is, hydrolysis of compound $\mathbf{1 8}$ with $2 \mathrm{~m}$ aqueous $\mathrm{LiOH}$ followed by ester formation with alcohol 11 in the presence of condensation agents such as $N^{\prime}$-(3dimethylaminopropyl)- $N$-ethylcarbodiimide $\quad$ (EDCI). ${ }^{[28]}$ However, purification of the free acid from the hydrolysis products of compound $\mathbf{1 8}$ encountered difficulties with respect to purity and recovery due to its good hydrophilicity. Fortunately, transesterification ${ }^{[29]}$ of $\mathbf{1 8}$ with the alkoxide anion derived from the treatment of fragment $\mathbf{1 1}$ with $\mathrm{NaH}$ in dry THF was carried out successfully presenting compound 19 in $75 \%$ yield. Desilylation of $\mathbf{1 9}$ with tetrabutylammonium fluoride (TBAF) in THF gave an $82 \%$ yield of $\mathbf{8}$, which was subjected to ring-closing metathesis (RCM) under the standard conditions. ${ }^{[30]}$ To our surprise, both $E$ and $Z$ isomeric olefins $(J=15.6 \mathrm{~Hz}$ for $E ; J=10.8 \mathrm{~Hz}$ for $Z$ ) were formed in a ratio of about 1.55:1 under our RCM conditions, and it was very hard to obtain the pure $E$ isomer (cochliomycin B) by routine column chromatography.
A literature search revealed that the vast majority of RCMbased macrocyclizations provide $E, Z$ mixtures, with the $E$ isomer usually being favored. ${ }^{[31]}$ In some cases, ${ }^{[32]} \mathrm{RCM}$ substrates having a free allylic alcohol gave low $E, Z$ selectivity and reactivity, as exemplified by Poulsen and Madsen's results for the RCM of carbohydrate-derived enynes. ${ }^{[33]} \mathrm{We}$ also found that the $E / Z$ selectivity differed slightly with reactant concentration, and the best result $\left(\mathbf{2 0}\right.$, based on ${ }^{1} \mathrm{H}$ NMR spectrum) was achieved by using the second-generation Grubbs catalyst at a concentration of $8 \times 10^{-4} \mathrm{M}$ in $\mathrm{CH}_{2} \mathrm{Cl}_{2}$. According to the RCM mechanism described by Grubbs $^{[34]}$ and Hillier ${ }^{[35]}$ and their co-workers, we envisaged that the bulky TBS-blocked allylic position might be a better substrate for the RCM reaction in favor of the $E$ isomer. Consequently, compound 19 was directly treated with the Grubbs II catalyst in $\mathrm{CH}_{2} \mathrm{Cl}_{2}$ at $40{ }^{\circ} \mathrm{C}$ to afford $67 \%$ yield of the $E$ isomer 21 exclusively. ${ }^{[36]}$ Final removal of TBS from 21 with TBAF in THF gave natural cochliomycin B (6) in $85 \%$ yield. In addition, removal of the acetonide functionality from compound $\mathbf{6}$ was achieved by treatment of 6 with $\mathrm{AcCl}$ in methanol (1\%) to afford another natural product zeaenol (22) in a yield of $91 \%$. The analytical data $\left({ }^{1} \mathrm{H},{ }^{13} \mathrm{C} \mathrm{NMR}\right.$, and optical rotation values) for both compounds 6 and 22 are consistent with those of the natural products.

\section{Conclusions}

Cochliomycin B (6) and zeaenol (22) have been synthesized from natural chiral template L-arabinose in overall yields of 4.8 and $4.3 \%$, respectively, by Takai olefination, 
Suzuki coupling, alkoxide-mediated transesterification, and RCM macrocyclization as the crucial steps. The syntheses of other structurally related RALs and studies on their biological activities are under way in our laboratory and the results will be reported in due course.

\section{Experimental Section}

General Methods: All reactions involving air- and moisture-sensitive reagents were carried out under nitrogen. Unless otherwise stated, materials were obtained from commercial suppliers and used without further purification. THF was distilled from $\mathrm{Na}$ and benzophenone. Dried $\mathrm{CH}_{2} \mathrm{Cl}_{2}$ and DMF were treated with $\mathrm{CaH}_{2}$. Column chromatography was carried out by using silica gel (100120 mesh). Routine monitoring of reactions was carried out by using silica gel 60 F254 TLC plates. Optical rotations were measured with a WZZ-2SS automatic digital polarimeter. ${ }^{1} \mathrm{H}$ and ${ }^{13} \mathrm{C}$ NMR spectra were recorded with a Bruker AVANCE-III $(400 \mathrm{MHz})$ spectrometer. Chemical shifts are given in ppm using $\mathrm{Me}_{4} \mathrm{Si}(\delta=0 \mathrm{ppm})$ as internal standard and coupling constants $(J)$ are reported in Hz. HRMS were measured with a Bruker microTOF Q II mass spectrometer. IR spectra were recorded using $\mathrm{KBr}$ with a NICOLET 8700 infrared spectrometer.

(S)-1-[(4R,5S)-5-(Hydroxymethyl)-2,2-dimethyl-1,3-dioxolan-4-yl]prop-2-en-1-ol (12): PTSA monohydrate (375 mg, $1.974 \mathrm{mmol})$ and 2,2-dimethoxypropane (DMOP; $62.5 \mathrm{~mL}, 0.508 \mathrm{~mol}$ ) were added to a stirred solution of L-arabinose $(25 \mathrm{~g}, 0.166 \mathrm{~mol})$ in dry DMF $(50 \mathrm{~mL})$. The mixture was stirred at room temp. for $2 \mathrm{~h}$ and then neutralized with $\mathrm{Et}_{3} \mathrm{~N}(1 \mathrm{~mL})$. The mixture was concentrated in vacuo and the residue purified by silica gel chromatography (EtOAc/petroleum ether, 2:1) to give 3,4- $O$-isopropylidene- $\beta$-L-arabinopyranose $(28.8 \mathrm{~g}, 91 \%)$ as a white solid. $n \mathrm{BuLi}(34 \mathrm{~mL}, 2.5 \mathrm{M}$ in hexane, $0.085 \mathrm{~mol}$ ) was added to a suspension of (methyl)triphenylphosphonium bromide $(30 \mathrm{~g}, 0.084 \mathrm{~mol})$ in dry THF $(100 \mathrm{~mL})$ at $0{ }^{\circ} \mathrm{C}$. After $1 \mathrm{~h}, 3,4-O$-isopropylidene- $\beta$-L-arabinopyranose $(4.5 \mathrm{~g}, 0.024 \mathrm{~mol})$ in THF $(20 \mathrm{~mL})$ was added dropwise to the above yellow suspension. The mixture was gradually warmed to room temp. with stirring. After $48 \mathrm{~h}$, the mixture was quenched with saturated aqueous $\mathrm{NH}_{4} \mathrm{Cl}(30 \mathrm{~mL})$ at $0{ }^{\circ} \mathrm{C}$, then extracted with EtOAc $(3 \times 50 \mathrm{~mL})$. The combined organic solvents were concentrated under reduced pressure and the orange residue purified by silica gel chromatography (EtOAc/petroleum ether, 1:1) to afford $12(3.2 \mathrm{~g}, 72 \%)$ as a colorless oil. $[\alpha]_{\mathrm{D}}^{25}=-9.8\left(c=0.75, \mathrm{CHCl}_{3}\right)$. ${ }^{1} \mathrm{H}$ NMR (400 MHz, $\left.\mathrm{CDCl}_{3}\right): \delta=5.92(\mathrm{ddd}, J=16.8,10.4,6.0 \mathrm{~Hz}$, $1 \mathrm{H}), 5.40(\mathrm{~d}, J=17.2 \mathrm{~Hz}, 1 \mathrm{H}), 5.27$ (d, $J=10.4 \mathrm{~Hz}, 1 \mathrm{H}), 4.27-$ $4.23(\mathrm{~m}, 2 \mathrm{H}), 4.14(\mathrm{dd}, J=6.4,4.4 \mathrm{~Hz}, 1 \mathrm{H}), 3.81-3.79(\mathrm{~m}, 2 \mathrm{H})$, 2.73 (br., $2 \mathrm{H}), 1.52(\mathrm{~s}, 3 \mathrm{H}), 1.38(\mathrm{~s}, 3 \mathrm{H}) \mathrm{ppm} .{ }^{13} \mathrm{C} \mathrm{NMR}$ $\left(100 \mathrm{MHz}, \mathrm{CDCl}_{3}\right): \delta=137.06,117.49,108.60,79.25,77.30,70.40$, 61.15, 27.36, 25.03 ppm. IR: $\tilde{v}=3390,2989,2936,2889,1646 \mathrm{~cm}^{-1}$. HRMS (ESI): calcd. for $\mathrm{C}_{9} \mathrm{H}_{16} \mathrm{O}_{4} \mathrm{Na}[\mathrm{M}+\mathrm{Na}]^{+} 211.0946$; found 211.0982 .

tert-Butyl $\{[(4 S, 5 S)-5-\{(S)-1-[($ tert-butyldimethylsilyl)oxy]allyl $\}-$ 2,2-dimethyl-1,3-dioxolan-4-yl|methoxy\}dimethylsilane (13): Imidazole $(7.16 \mathrm{~g}, 0.105 \mathrm{~mol})$ and TBSCl $(5.265 \mathrm{~g}, 0.035 \mathrm{~mol})$ were added to a solution of compound $12(3 \mathrm{~g}, 0.016 \mathrm{~mol})$ in $\mathrm{CH}_{2} \mathrm{Cl}_{2}$ $(20 \mathrm{~mL})$. After $2 \mathrm{~h}$ the reaction mixture was quenched with saturated aqueous $\mathrm{NaHCO}_{3}(10 \mathrm{~mL})$, extracted with $\mathrm{CH}_{2} \mathrm{Cl}_{2}(2 \times$ $10 \mathrm{~mL}$ ), washed with brine, and the solvents evaporated in vacuo. Column chromatography of the residue on silica gel (EtOAc/petroleum ether, 1:50) yielded $\mathbf{1 3}(6.3 \mathrm{~g}, 95 \%)$ as a colorless oil. $[\alpha]_{\mathrm{D}}^{25}=$ $+35.5\left(c=0.22, \mathrm{CHCl}_{3}\right) .{ }^{1} \mathrm{H}$ NMR $\left(400 \mathrm{MHz}, \mathrm{CDCl}_{3}\right): \delta=6.05$ (ddd, $J=17.2,10.8,4.8 \mathrm{~Hz}, 1 \mathrm{H}), 5.35$ (dt, $J=17.2,2.0 \mathrm{~Hz}, 1 \mathrm{H}$ ), $5.15(\mathrm{dt}, J=10.8,2.0 \mathrm{~Hz}, 1 \mathrm{H}), 4.39-4.35(\mathrm{~m}, 1 \mathrm{H}), 4.12(\mathrm{q}, J=$ $6.0 \mathrm{~Hz}, 1 \mathrm{H}), 3.98(\mathrm{t}, J=6.8 \mathrm{~Hz}, 1 \mathrm{H}), 3.87(\mathrm{dd}, J=10.8,6.0 \mathrm{~Hz}$, $1 \mathrm{H}), 3.69(\mathrm{dd}, J=11.2,5.6 \mathrm{~Hz}, 1 \mathrm{H}), 1.44(\mathrm{~s}, 3 \mathrm{H}), 1.32(\mathrm{~s}, 3 \mathrm{H})$, $0.91(\mathrm{~s}, 9 \mathrm{H}), 0.89(\mathrm{~s}, 9 \mathrm{H}), 0.07(\mathrm{~s}, 6 \mathrm{H}), 0.06(\mathrm{~s}, 6 \mathrm{H}) \mathrm{ppm} .{ }^{13} \mathrm{C}$ NMR $\left(100 \mathrm{MHz}, \mathrm{CDCl}_{3}\right): \delta=138.03,115.60,108.07,80.82,78.28$, $72.20,62.38,27.65,26.04,25.95,25.42,18.51,18.46,-4.42,-4.65$, $-5.24,-5.28$ ppm. IR: $\tilde{v}=2959,2936,2860,1646,1473 \mathrm{~cm}^{-1}$. HRMS (ESI): calcd. for $\mathrm{C}_{21} \mathrm{H}_{44} \mathrm{O}_{4} \mathrm{Si}_{2} \mathrm{Na}[\mathrm{M}+\mathrm{Na}]^{+} 439.2676$; found 439.2714

[(4S,5S)-5-\{(S)-1-[(tert-Butyldimethylsilyl)oxy]allyl\}-2,2-dimethyl1,3-dioxolan-4-yl]methanol (14): A solution of 13 (3 g, $7.2 \mathrm{mmol})$ in $95 \%$ ethanol $(20 \mathrm{~mL})$ was treated with PPTS $(210 \mathrm{mg}$, $0.835 \mathrm{mmol})$. The reaction was monitored by TLC until all starting material had disappeared. Then $\mathrm{Et}_{3} \mathrm{~N}(0.5 \mathrm{~mL})$ was added to neutralize the acid and the solution concentrated under reduced pressure. Purification of the residue by silica gel chromatography (EtOAc/petroleum ether, 1:3) yielded $\mathbf{1 4}(1.764 \mathrm{~g}, 81 \%)$ as a colorless oil. $[\alpha]_{\mathrm{D}}^{25}=-93\left(c=0.8, \mathrm{CHCl}_{3}\right) .{ }^{1} \mathrm{H} \mathrm{NMR}\left(400 \mathrm{MHz}, \mathrm{CDCl}_{3}\right)$ : $\delta=6.03(\mathrm{ddd}, J=17.2,10.8,4.8 \mathrm{~Hz}, 1 \mathrm{H}), 5.35(\mathrm{dt}, J=17.2$, $2.0 \mathrm{~Hz}, 1 \mathrm{H}), 5.22(\mathrm{dt}, J=10.4,2.0 \mathrm{~Hz}, 1 \mathrm{H}), 4.38-4.34(\mathrm{~m}, 1 \mathrm{H})$, $4.28(\mathrm{q}, J=6.4 \mathrm{~Hz}, 1 \mathrm{H}), 4.18(\mathrm{t}, J=6.4 \mathrm{~Hz}, 1 \mathrm{H}), 3.89-3.83(\mathrm{~m}$, $1 \mathrm{H}), 3.72-3.68$ (m, $1 \mathrm{H}), 2.69$ (br., $1 \mathrm{H}), 1.47$ (s, $3 \mathrm{H}), 1.35$ (s, 3 $\mathrm{H}), 0.91(\mathrm{~s}, 9 \mathrm{H}), 0.10(\mathrm{~s}, 3 \mathrm{H}), 0.08(\mathrm{~s}, 3 \mathrm{H}) \mathrm{ppm} .{ }^{13} \mathrm{C} \mathrm{NMR}$ $\left(100 \mathrm{MHz}, \mathrm{CDCl}_{3}\right): \delta=136.85,116.70,108.58,79.49,78.21,73.15$, $61.13,27.48,25.96,25.20,18.44,-4.60,-4.79 \mathrm{ppm}$. IR: $\tilde{v}=3346$, 2939, 2857, $1464 \mathrm{~cm}^{-1}$. HRMS (ESI): calcd. for $\mathrm{C}_{15} \mathrm{H}_{30} \mathrm{O}_{4} \mathrm{SiNa}[\mathrm{M}$ $+\mathrm{Na}]^{+} 325.1811$; found 325.1811 .

(4R,5S)-5-\{(S)-1-[(tert-Butyldimethylsilyl)oxy]allyl\}-2,2-dimethyl1,3-dioxolane-4-carbaldehyde (15): $\mathrm{NaHCO}_{3}$ (1.176 g, $\left.14.01 \mathrm{mmol}\right)$ and Dess-Martin periodinane $(1.98 \mathrm{~g}, 4.67 \mathrm{mmol})$ were sequentially added to a solution of compound $14(950 \mathrm{mg}, 3.144 \mathrm{mmol})$ in $\mathrm{CH}_{2} \mathrm{Cl}_{2}(15 \mathrm{~mL})$. The mixture was stirred for $1 \mathrm{~h}$ and then poured into cold water $(10 \mathrm{~mL})$. The organic layer was separated and the aqueous phase extracted with $\mathrm{CH}_{2} \mathrm{Cl}_{2}(2 \times 30 \mathrm{~mL})$. The combined organic layers were evaporated in vacuo and the residue purified by silica gel chromatography (EtOAc/petroleum ether, $1: 16)$ to afford $15(811 \mathrm{mg}, 86 \%)$ as a yellowish oil. $[\alpha]_{\mathrm{D}}^{25}=+72(c$ $\left.=0.85, \mathrm{CHCl}_{3}\right) \cdot{ }^{1} \mathrm{H}$ NMR $\left(400 \mathrm{MHz}, \mathrm{CDCl}_{3}\right): \delta=9.73(\mathrm{~d}, J=$ $2.0 \mathrm{~Hz}, 1 \mathrm{H}), 5.94(\mathrm{ddd}, J=17.2,10.4,2.8 \mathrm{~Hz}, 1 \mathrm{H}), 5.26(\mathrm{dt}, J=$ $17.6,1.6 \mathrm{~Hz}, 1 \mathrm{H}), 5.18(\mathrm{dt}, J=10.4,1.6 \mathrm{~Hz}, 1 \mathrm{H}), 4.40(\mathrm{dd}, J=$ 7.6, $2.0 \mathrm{~Hz}, 1 \mathrm{H}), 4.34(\mathrm{dd}, J=7.6,4.0 \mathrm{~Hz}, 1 \mathrm{H}), 4.27-4.26(\mathrm{~m}, 1$ $\mathrm{H}), 1.56(\mathrm{~s}, 3 \mathrm{H}), 1.35(\mathrm{~s}, 3 \mathrm{H}), 0.87(\mathrm{~s}, 9 \mathrm{H}), 0.03(\mathrm{~s}, 3 \mathrm{H}), 0.02(\mathrm{~s}, 3$ H) ppm. ${ }^{13} \mathrm{C} \mathrm{NMR}\left(100 \mathrm{MHz}, \mathrm{CDCl}_{3}\right): \delta=200.30,137.30,117.58$, $110.89,83.02,81.41,72.62,26.81,26.00,25.21,18.30,-3.72$, -4.59 ppm. IR: $\tilde{v}=2930,2860,1737,1646,1467 \mathrm{~cm}^{-1}$. HRMS (ESI): calcd. for $\mathrm{C}_{15} \mathrm{H}_{28} \mathrm{O}_{4} \mathrm{SiNa}[\mathrm{M}+\mathrm{Na}]^{+} 323.1655$; found 323.1615 .

tert-Butyl(\{(S)-1-[(4S,5S)-5-(2-methoxyvinyl)-2,2-dimethyl-1,3-dioxolan-4-yl]allyl\} oxy)dimethylsilane (16): $t \mathrm{BuOK}$ (0.556 g, $4.95 \mathrm{mmol})$ was added to a suspension of (methoxymethyl)triphenylphosphonium chloride $(1.34 \mathrm{~g}, 3.91 \mathrm{mmol})$ in dry THF $(12 \mathrm{~mL})$ at $0{ }^{\circ} \mathrm{C}$. The mixture was stirred for $45 \mathrm{~min}$ and a solution of aldehyde $\mathbf{1 5}(1.0 \mathrm{~g}$, $3.33 \mathrm{mmol})$ in THF $(8 \mathrm{~mL})$ was added. After $1 \mathrm{~h}$, the mixture was quenched with saturated aqueous $\mathrm{NH}_{4} \mathrm{Cl}(5 \mathrm{~mL})$, extracted with EtOAc $(2 \times 20 \mathrm{~mL})$, and dried. Removal of the solvent gave an oil which was subjected to silica gel flash column chromatography (EtOAc/petroleum ether, 1:16) to provide methyl enol ether $\mathbf{1 6}$ (842 $\mathrm{mg}, E, Z$ mixture, $77 \%$ ) as a colorless oil.

2-[(4S,5S)-5-\{(S)-1-[(tert-Butyldimethylsilyl)oxy]allyl\}-2,2-dimethyl1,3-dioxolan-4-yl]acetaldehyde (17): The methyl enol ether 16 (400 mg, $1.218 \mathrm{mmol}$ ) was dissolved in THF $(40 \mathrm{~mL})$ at $0{ }^{\circ} \mathrm{C}$ and 
then mercuric acetate $(956 \mathrm{mg}, 2.686 \mathrm{mmol})$ in cooled water $(10 \mathrm{~mL})$ was added dropwise. The suspension was stirred for $1 \mathrm{~h}$ and then $8 \%$ aqueous KI solution $(10 \mathrm{~mL})$ was then added to quench the reaction. The reaction mixture was extracted with EtOAc $(3 \times 20 \mathrm{~mL})$ and the combined organic solvents were dried with anhydrous $\mathrm{Na}_{2} \mathrm{SO}_{4}$ and concentrated in vacuo to afford the crude aldehyde. Purification on silica gel (EtOAc/petroleum ether, 1:16) afforded $17(287 \mathrm{mg}, 75 \%)$ as a colorless oil. $[\alpha]_{\mathrm{D}}^{25}=-148(c$ $\left.=0.3, \mathrm{CHCl}_{3}\right) .{ }^{1} \mathrm{H}$ NMR $\left(400 \mathrm{MHz}, \mathrm{CDCl}_{3}\right): \delta=9.77(\mathrm{~s}, 1 \mathrm{H})$, $5.99-5.92(\mathrm{~m}, 1 \mathrm{H}), 5.32(\mathrm{dd}, J=17.2,1.2 \mathrm{~Hz}, 1 \mathrm{H}), 5.22(\mathrm{dd}, J=$ $10.8,1.2 \mathrm{~Hz}, 1 \mathrm{H}), 4.70-4.64(\mathrm{~m}, 1 \mathrm{H}), 4.23-4.21(\mathrm{~m}, 1 \mathrm{H}), 4.13-$ $4.10(\mathrm{~m}, 1 \mathrm{H}), 2.89-2.83(\mathrm{~m}, 2 \mathrm{H}), 1.47(\mathrm{~s}, 3 \mathrm{H}), 1.35(\mathrm{~s}, 3 \mathrm{H}), 0.89$ $(\mathrm{d}, J=1.6 \mathrm{~Hz}, 9 \mathrm{H}), 0.07(\mathrm{dd}, J=2.0 \mathrm{~Hz}, 6 \mathrm{H}) \mathrm{ppm} .{ }^{13} \mathrm{C} \mathrm{NMR}$ $\left(100 \mathrm{MHz}, \mathrm{CDCl}_{3}\right): \delta=200.76,137.14,117.01,108.75,79.56$, $73.27,72.16,44.16,27.46,26.04,25.41,18.48,-4.38,-4.64 \mathrm{ppm}$. IR: $\tilde{v}=2936,2857,1725,1655,1473 \mathrm{~cm}^{-1}$. HRMS (ESI): calcd. for $\mathrm{C}_{16} \mathrm{H}_{30} \mathrm{O}_{4} \mathrm{SiNa}[\mathrm{M}+\mathrm{Na}]^{+}$337.1811; found 337.1775.

tert-Butyl\{[(S)-1-\{(4S,5S)-5-[(E)-3-iodoallyl]-2,2-dimethyl-1,3-dioxolan-4-yl\}allyl]oxy \} dimethylsilane (10): Anhydrous $\mathrm{CrCl}_{2}$ (626 mg, $5.088 \mathrm{mmol})$ was suspended in dry THF $(15 \mathrm{~mL})$ under nitrogen. A solution of aldehyde $17(200 \mathrm{mg}, 0.636 \mathrm{mmol})$ and iodoform $(752 \mathrm{mg}, 1.908 \mathrm{mmol})$ in THF $(8 \mathrm{~mL})$ was then added dropwise to the suspension at $0{ }^{\circ} \mathrm{C}$. After stirring at $0{ }^{\circ} \mathrm{C}$ for $3 \mathrm{~h}$, the reaction mixture was poured into water $(10 \mathrm{~mL})$, extracted with diethyl ether $(3 \times 25 \mathrm{~mL})$, and evaporated in vacuo. The residue was purified by silica gel chromatography (EtOAc/petroleum ether, 1:250) to afford vinyl iodide $\mathbf{1 0}(181 \mathrm{mg}, 65 \%)$ as a colorless oil. $[\alpha]_{\mathrm{D}}^{25}=-150\left(c=0.6, \mathrm{CHCl}_{3}\right) .{ }^{1} \mathrm{H} \mathrm{NMR}\left(400 \mathrm{MHz}, \mathrm{CDCl}_{3}\right): \delta=$ $6.59(\mathrm{dt}, J=14.4,7.2 \mathrm{~Hz}, 1 \mathrm{H}), 6.09(\mathrm{~d}, J=14.4 \mathrm{~Hz}, 1 \mathrm{H}), 5.91$ (ddd, $J=16.8,10.4,5.6 \mathrm{~Hz}, 1 \mathrm{H}), 5.32(\mathrm{~d}, J=17.6 \mathrm{~Hz}, 1 \mathrm{H}), 5.19$ $(\mathrm{d}, J=10.4 \mathrm{~Hz}, 1 \mathrm{H}), 4.22(\mathrm{t}, J=6.4 \mathrm{~Hz}, 1 \mathrm{H}), 4.11-4.07(\mathrm{~m}, 1$ H), 3.99 (t, $J=6.4 \mathrm{~Hz}, 1 \mathrm{H}), 2.41-2.36(\mathrm{~m}, 2 \mathrm{H}), 1.47$ (s, $3 \mathrm{H}), 1.33$ $(\mathrm{s}, 3 \mathrm{H}), 0.90(\mathrm{~s}, 9 \mathrm{H}), 0.08(\mathrm{~s}, 3 \mathrm{H}), 0.07(\mathrm{~s}, 3 \mathrm{H}) \mathrm{ppm} .{ }^{13} \mathrm{C}$ NMR $\left(100 \mathrm{MHz}, \mathrm{CDCl}_{3}\right): \delta=143.21,137.24,116.93,108.48,80.54$, $76.38,72.95,36.74,27.87,26.03,25.68,18.50,-4.32,-4.54 \mathrm{ppm}$. IR: $\tilde{v}=2933,2857,1614,1470 \mathrm{~cm}^{-1}$. HRMS (ESI): calcd. for $\mathrm{C}_{17} \mathrm{H}_{31} \mathrm{O}_{3} \mathrm{ISiNa}[\mathrm{M}+\mathrm{Na}]^{+}$461.0985; found 461.0964.

5-\{(E)-3-[(4S,5S)-5-\{(S)-1-[(tert-Butyldimethylsilyl)oxy]allyl\}-2,2-dimethyl-1,3-dioxolan-4-yl|prop-1-en-1-yl\}-7-methoxy-2,2-dimethyl4H-benzo[d][1,3]dioxin-4-one (18): Degassed solvent $\left(\mathrm{THF} / \mathrm{H}_{2} \mathrm{O}\right.$, $10: 1,11 \mathrm{~mL}$ ) was added under nitrogen to a mixture of vinyl iodide 10 (144 mg, $0.328 \mathrm{mmol})$, boronate 9 (141 mg, $0.422 \mathrm{mmol})$, $\mathrm{Cs}_{2} \mathrm{CO}_{3}$ (426 mg, $\left.1.308 \mathrm{mmol}\right)$, and $\left[\mathrm{Pd}\left(\mathrm{PPh}_{3}\right)_{4}\right]$ (cat.). The solution was heated at $70{ }^{\circ} \mathrm{C}$ for $2 \mathrm{~h}$ (monitoring with TLC). After cooling to room temp., saturated aqueous $\mathrm{NH}_{4} \mathrm{Cl}(5 \mathrm{~mL})$ was added and the mixture extracted with EtOAc $(3 \times 10 \mathrm{~mL})$. The organic layer was dried with $\mathrm{Na}_{2} \mathrm{SO}_{4}$ and then concentrated to dryness. The residue was purified by silica gel column chromatography (EtOAc/petroleum ether, 1:6) to afford $\mathbf{1 8}(116 \mathrm{mg}, 68 \%)$ as a yellowish oil. $[\alpha]_{\mathrm{D}}^{25}=-163.3\left(c=0.6, \mathrm{CHCl}_{3}\right) .{ }^{1} \mathrm{H} \mathrm{NMR}\left(400 \mathrm{MHz}, \mathrm{CDCl}_{3}\right): \delta=$ $7.51(\mathrm{~d}, J=16.0 \mathrm{~Hz}, 1 \mathrm{H}), 6.79(\mathrm{~d}, J=2.4 \mathrm{~Hz}, 1 \mathrm{H}), 6.33(\mathrm{~d}, J=$ $2.4 \mathrm{~Hz}, 1 \mathrm{H}), 6.27(\mathrm{dt}, J=17.6,7.2 \mathrm{~Hz}, 1 \mathrm{H}), 5.93$ (ddd, $J=16.8$, $10.4,6.0 \mathrm{~Hz}, 1 \mathrm{H}), 5.37(\mathrm{~d}, J=17.6 \mathrm{~Hz}, 1 \mathrm{H}), 5.21(\mathrm{~d}, J=10.4 \mathrm{~Hz}$, $1 \mathrm{H}), 4.29(\mathrm{t}, J=6.8 \mathrm{~Hz}, 1 \mathrm{H}), 4.20$ (ddd, $J=9.6,5.6,4.0 \mathrm{~Hz}, 1$ $\mathrm{H}), 4.01(\mathrm{t}, J=6.0 \mathrm{~Hz}, 1 \mathrm{H}), 3.84(\mathrm{~s}, 3 \mathrm{H}), 2.63-2.57(\mathrm{~m}, 2 \mathrm{H}), 1.69$ $(\mathrm{s}, 6 \mathrm{H}), 1.51(\mathrm{~s}, 3 \mathrm{H}), 1.35(\mathrm{~s}, 3 \mathrm{H}), 0.91(\mathrm{~s}, 9 \mathrm{H}), 0.11(\mathrm{~s}, 3 \mathrm{H})$, $0.08(\mathrm{~s}, 3 \mathrm{H}) \mathrm{ppm} .{ }^{13} \mathrm{C} \mathrm{NMR}\left(100 \mathrm{MHz}, \mathrm{CDCl}_{3}\right): \delta=164.93$, 160.43, 158.84, 144.01, 137.38, 135.39, 131.67, 130.31, 117.04, $108.44,108.38,105.13,103.88,100.47,81.12,77.40,72.97,55.81$, $34.04,29.88,28.02,26.08,25.90,25.83,25.80,18.56,-4.23$, $-4.46 \mathrm{ppm}$. IR: $\tilde{v}=2927,2854,1734,1608,1576 \mathrm{~cm}^{-1}$. HRMS (ESI): calcd. for $\mathrm{C}_{28} \mathrm{H}_{42} \mathrm{O}_{7} \mathrm{SiNa}[\mathrm{M}+\mathrm{Na}]^{+}$541.2597; found 541.2603 .
$(S)$-Pent-4-en-2-yl 2-\{(E)-3-[(4S,5S)-5-\{(S)-1-I(tert-Butyldimethylsilyl)oxy]allyl\}-2,2-dimethyl-1,3-dioxolan-4-yl]prop-1-en-1-yl\}-6hydroxy-4-methoxybenzoate (19): To a solution of pent-4-en-2-ol (11; $90 \mathrm{mg}, 1.046 \mathrm{mmol})$ in dry THF was added $\mathrm{NaH}(62 \mathrm{mg}, 60 \%$ in mineral oil, $1.55 \mathrm{mmol}$ ) under nitrogen at $0{ }^{\circ} \mathrm{C}$. The reaction mixture was stirred at this temperature for $30 \mathrm{~min}$ and then a solution of $18(100 \mathrm{mg}, 0.193 \mathrm{mmol})$ in THF $(5 \mathrm{~mL})$ was added to the above suspension. Saturated aqueous $\mathrm{NH}_{4} \mathrm{Cl}(2 \mathrm{~mL})$ was added to quench the reaction until TLC showed completion of the reaction (about $4 \mathrm{~h})$. The mixture was extracted with EtOAc $(3 \times 5 \mathrm{~mL})$, concentrated under reduced pressure, and the residue purified by silica gel column chromatography (EtOAc/petroleum ether, 1:25) to afford $19(79 \mathrm{mg}, 75 \%)$ as a colorless oil. $[\alpha]_{\mathrm{D}}^{25}=-59.4(c=0.65$, $\mathrm{CHCl}_{3}$ ). ${ }^{1} \mathrm{H} \mathrm{NMR}\left(400 \mathrm{MHz}, \mathrm{CDCl}_{3}\right): \delta=11.74(\mathrm{~s}, 1 \mathrm{H}), 7.04(\mathrm{~d}$, $J=15.6 \mathrm{~Hz}, 1 \mathrm{H}), 6.48(\mathrm{~d}, J=2.8 \mathrm{~Hz}, 1 \mathrm{H}), 6.38(\mathrm{~d}, J=2.4 \mathrm{~Hz}$, $1 \mathrm{H}), 6.04-5.92(\mathrm{~m}, 2 \mathrm{H}), 5.86-5.76(\mathrm{~m}, 1 \mathrm{H}), 5.35(\mathrm{~d}, J=17.6 \mathrm{~Hz}$, $1 \mathrm{H}), 5.27-5.20(\mathrm{~m}, 2 \mathrm{H}), 5.15-5.10(\mathrm{~m}, 2 \mathrm{H}), 4.28-4.27(\mathrm{~m}, 1 \mathrm{H})$, 4.18 (ddd, $J=9.6,6.0,3.6 \mathrm{~Hz}, 1 \mathrm{H}), 4.03(\mathrm{t}, J=6.0 \mathrm{~Hz}, 1 \mathrm{H}), 3.81$ $(\mathrm{s}, 3 \mathrm{H}), 2.63-2.38(\mathrm{~m}, 4 \mathrm{H}), 1.50(\mathrm{~s}, 3 \mathrm{H}), 1.35(\mathrm{~d}, J=6.4 \mathrm{~Hz}, 3$ $\mathrm{H}), 1.34$ (s, $3 \mathrm{H}), 0.92$ (s, $9 \mathrm{H}), 0.10$ (s, $3 \mathrm{H}), 0.09$ (s, $3 \mathrm{H}) \mathrm{ppm} .{ }^{13} \mathrm{C}$ NMR $\left(100 \mathrm{MHz}, \mathrm{CDCl}_{3}\right): \delta=170.92,165.13,164.11,143.51$, $137.62,133.52,133.32,129.15,118.40,116.70,108.52,108.30$, $104.21,99.96,80.72,73.30,72.00,55.60,40.38,33.73,29.89,27.88$, $26.07,25.71,19.79,18.52,-4.28,-4.51 \mathrm{ppm} . \mathrm{IR}: \tilde{v}=2933$, 2857, 1743, 1649, 1611, $1581 \mathrm{~cm}^{-1}$. HRMS (ESI): calcd. for $\mathrm{C}_{30} \mathrm{H}_{46} \mathrm{O}_{7} \mathrm{SiNa}[\mathrm{M}+\mathrm{Na}]^{+}$569.2911; found 569.2890.

(S)-Pent-4-en-2-yl 2-Hydroxy-6- $[(E)-3-\{(4 S, 5 R)-5-[(S)-1-$ hydroxyallyl]-2,2-dimethyl-1,3-dioxolan-4-yl\}prop-1-en-1-yl]-4-methoxybenzoate (8): A solution of 19 ( $90 \mathrm{mg}, 0.165 \mathrm{mmol})$ in THF $(5 \mathrm{~mL})$ was treated with TBAF $(60 \mathrm{mg}, 0.189 \mathrm{mmol})$ at room temp. After the starting material had disappeared, the solvent was removed and the residue subjected directly to silica gel column chromatography (EtOAc/petroleum ether, 1:3) to afford $8(58 \mathrm{mg}$, $82 \%)$ as a colorless oil. $[\alpha]_{\mathrm{D}}^{25}=+33.3\left(c=0.3, \mathrm{CHCl}_{3}\right) .{ }^{1} \mathrm{H} \mathrm{NMR}$ $\left(400 \mathrm{MHz}, \mathrm{CDCl}_{3}\right): \delta=11.74(\mathrm{~s}, 1 \mathrm{H}), 7.07(\mathrm{~d}, J=15.6 \mathrm{~Hz}, 1 \mathrm{H})$, $6.45(\mathrm{~d}, J=2.4 \mathrm{~Hz}, 1 \mathrm{H}), 6.39(\mathrm{~d}, J=2.8 \mathrm{~Hz}, 1 \mathrm{H}), 5.95-5.78(\mathrm{~m}$, $3 \mathrm{H}), 5.42(\mathrm{~d}, J=17.6 \mathrm{~Hz}, 1 \mathrm{H}), 5.30-5.23(\mathrm{~m}, 2 \mathrm{H}), 5.16-5.10(\mathrm{~m}$, $2 \mathrm{H}), 4.30-4.27(\mathrm{~m}, 1 \mathrm{H}), 4.22-4.21(\mathrm{~m}, 1 \mathrm{H}), 4.07(\mathrm{t}, J=5.6 \mathrm{~Hz}$, $1 \mathrm{H}), 3.82(\mathrm{~s}, 3 \mathrm{H}), 2.68-2.62(\mathrm{~m}, 1 \mathrm{H}), 2.56-2.40(\mathrm{~m}, 3 \mathrm{H}), 2.36$ $(\mathrm{d}, J=5.6 \mathrm{~Hz}, 1 \mathrm{H}), 1.53(\mathrm{~s}, 3 \mathrm{H}), 1.38(\mathrm{~s}, 3 \mathrm{H}), 1.36(\mathrm{~d}, J=6.4 \mathrm{~Hz}$, $3 \mathrm{H}) \mathrm{ppm} .{ }^{13} \mathrm{C} \mathrm{NMR}\left(100 \mathrm{MHz}, \mathrm{CDCl}_{3}\right): \delta=170.72,165.11$, 164.04, 143.19, 137.37, 133.75, 133.44, 128.03, 118.32, 117.57, $108.51,108.33,104.18,99.95,79.89,71.99,70.83,55.49,40.26$, $33.81,27.70,25.18,19.72$ ppm. IR: $\tilde{v}=3440,2924,2851,2320$, $1728,1461 \mathrm{~cm}^{-1}$. HRMS (ESI): calcd. for $\mathrm{C}_{24} \mathrm{H}_{32} \mathrm{O}_{7} \mathrm{Na}[\mathrm{M}+\mathrm{Na}]^{+}$ 455.2046; found 455.2039

(3aS, 4S,5E,8S,15E,17aS)-4-(tert-Butyldimethylsilyloxy)-11hydroxy-13-methoxy-2,2,8-trimethyl-7,8,17,17a-tetrahydro-3a $H$ benzo[c][1,3]dioxolo[4,5-h][1]oxacyclotetradecin-10(4H)-one (21): The second-generation Grubbs catalyst $(12 \mathrm{mg}, 0.015 \mathrm{mmol})$ was added to a solution of $19(60 \mathrm{mg}, 0.11 \mathrm{mmol})$ in degassed dry $\mathrm{CH}_{2} \mathrm{Cl}_{2}(180 \mathrm{~mL})$. The mixture was stirred at $40{ }^{\circ} \mathrm{C}$ for $12 \mathrm{~h}$, the solvent was removed under reduced pressure, and the residue purified by silica gel column chromatography (EtOAc/petroleum ether, 1:25) to afford $21(38.1 \mathrm{mg}, 67 \%)$ as a colorless oil. $[\alpha]_{\mathrm{D}}^{25}=-112.2$ $\left(c=0.18, \mathrm{CHCl}_{3}\right) .{ }^{1} \mathrm{H} \mathrm{NMR}\left(400 \mathrm{MHz}, \mathrm{CDCl}_{3}\right): \delta=11.69(\mathrm{~s}, 1$ $\mathrm{H}), 6.88(\mathrm{~d}, J=15.6 \mathrm{~Hz}, 1 \mathrm{H}), 6.39(\mathrm{~d}, J=2.4 \mathrm{~Hz}, 1 \mathrm{H}), 6.37(\mathrm{~d}$, $J=2.4 \mathrm{~Hz}, 1 \mathrm{H}), 5.86(\mathrm{ddd}, J=15.2,7.6,4.8 \mathrm{~Hz}, 1 \mathrm{H}), 5.76$ (ddd, $J=15.2,7.2,4.0 \mathrm{~Hz}, 1 \mathrm{H}), 5.56(\mathrm{dd}, J=15.6,8.0 \mathrm{~Hz}, 1 \mathrm{H}), 5.39$ $5.35(\mathrm{~m}, 1 \mathrm{H}), 4.28(\mathrm{t}, J=8.4 \mathrm{~Hz}, 1 \mathrm{H}), 4.15-4.11(\mathrm{~m}, 1 \mathrm{H}), 3.99$ $(\mathrm{dd}, J=8.8,5.2 \mathrm{~Hz}, 1 \mathrm{H}), 3.81(\mathrm{~s}, 3 \mathrm{H}), 2.68-2.44(\mathrm{~m}, 4 \mathrm{H}), 1.49$ (s, $3 \mathrm{H}), 1.42(\mathrm{~d}, J=6.4 \mathrm{~Hz}, 3 \mathrm{H}), 1.36(\mathrm{~s}, 3 \mathrm{H}), 0.86(\mathrm{~s}, 9 \mathrm{H}), 0.09$ $(\mathrm{s}, 3 \mathrm{H}), 0.05(\mathrm{~s}, 3 \mathrm{H}) \mathrm{ppm} .{ }^{13} \mathrm{C} \mathrm{NMR}\left(100 \mathrm{MHz}, \mathrm{CDCl}_{3}\right): \delta=$ 
$171.04,165.08,164.16,143.27,133.48,132.98,128.98,128.10$, $107.82,104.33,100.16,81.21,73.02,70.93,55.49,37.81,34.13$, $28.61,26.07,25.90,19.13,18.35,-3.99,-4.11 \mathrm{ppm}$. IR: $\tilde{v}=$ 2936, 2854, 1649, 1608, $1467 \mathrm{~cm}^{-1}$. HRMS (ESI): calcd. for $\mathrm{C}_{28} \mathrm{H}_{42} \mathrm{O}_{7} \mathrm{SiNa}[\mathrm{M}+\mathrm{Na}]^{+}: 541.2597$; found 541.2578 .

\section{Cochliomycin B (6)}

Method A: Compound 8 (40 mg, $0.092 \mathrm{mmol}$ ) was dissolved in dry degassed DCM $\left(116 \mathrm{~mL}, c=8.0 \times 10^{-4} \mathrm{M}\right)$, the solution was treated with the second-generation Grubbs catalyst $(8.5 \mathrm{mg}, 0.01 \mathrm{mmol})$, and the mixture was stirred at $40{ }^{\circ} \mathrm{C}$ for $4 \mathrm{~h}$. Then the solvent was removed under reduced pressure and the residue was purified by HPLC to afford $20\left[15.9 \mathrm{mg}, 42.5 \% ; E / Z \approx 1.55: 1\right.$ based on the ${ }^{1} \mathrm{H}$ NMR spectrum: $J=15.6 \mathrm{~Hz}$ for $E, J=10.8 \mathrm{~Hz}$ for $Z$; the $E$ enantiomer is cochliomycin B (6)].

Method B: TBAF (60 mg, $0.186 \mathrm{mmol}$ ) was added to a solution of compound 21 (60 mg, $0.116 \mathrm{mmol})$ in THF $(5 \mathrm{~mL})$ at room temp. After completion of the reaction, the solvent was removed under reduced pressure and the residue purified by silica gel column chromatography (EtOAc/petroleum ether, 1:3) to afford pure 6 $(39.8 \mathrm{mg}, 85 \%)$ as an amorphous solid. $[\alpha]_{\mathrm{D}}^{25}=+38.8(c=0.08$, $\mathrm{MeOH}) .{ }^{1} \mathrm{H}$ NMR (400 MHz, $\mathrm{CDCl}_{3}$ ): $\delta=11.52$ (s, $1 \mathrm{H}$ ), 7.01 (dd, $J=16.0,2.4 \mathrm{~Hz}, 1 \mathrm{H}), 6.41(\mathrm{~d}, J=2.4 \mathrm{~Hz}, 1 \mathrm{H}), 6.39(\mathrm{~d}, J=$ $2.4 \mathrm{~Hz}, 1 \mathrm{H}), 6.08$ (ddd, $J=15.2,9.2,4.4 \mathrm{~Hz}, 1 \mathrm{H}), 5.65$ (ddd, $J=$ $15.2,9.2,3.6 \mathrm{~Hz}, 1 \mathrm{H}), 5.48-5.42(\mathrm{~m}, 2 \mathrm{H}), 4.36$ (ddd, $J=11.6$, $4.4,3.2 \mathrm{~Hz}, 1 \mathrm{H}), 4.12(\mathrm{t}, J=8.8 \mathrm{~Hz}, 1 \mathrm{H}), 3.86(\mathrm{dd}, J=10.0$, $4.8 \mathrm{~Hz}, 1 \mathrm{H}), 3.82(\mathrm{~s}, 3 \mathrm{H}), 3.03(\mathrm{~s}, 1 \mathrm{H}), 2.75-2.74(\mathrm{~m}, 1 \mathrm{H}), 2.63$ $2.58(\mathrm{~m}, 1 \mathrm{H}), 2.55-2.45(\mathrm{~m}, 1 \mathrm{H}), 2.45-2.40(\mathrm{~m}, 1 \mathrm{H}), 1.53(\mathrm{~s}, 3$ $\mathrm{H}), 1.45(\mathrm{~d}, J=6.4 \mathrm{~Hz}, 3 \mathrm{H}), 1.42(\mathrm{~s}, 3 \mathrm{H}) \mathrm{ppm} .{ }^{13} \mathrm{C} \mathrm{NMR}$ $\left(100 \mathrm{MHz}, \mathrm{CDCl}_{3}\right): \delta=170.63,164.83,164.11,142.60,134.53$, $132.90,130.48,126.30,107.90,107.67,104.58,100.15,79.54,70.60$, 69.74, 55.52, 38.30, 31.38, 28.47, 25.96, 18.86 ppm. IR: $\tilde{v}=3440$, 2930, 2851, 2381, 2326, $1631 \mathrm{~cm}^{-1}$. HRMS (ESI): calcd. for $\mathrm{C}_{22} \mathrm{H}_{27} \mathrm{O}_{7}[\mathrm{M}-\mathrm{H}]^{-}$403.1757; found 403.1773.

Zeaenol (22): Compound 6 (30 mg, $0.074 \mathrm{mmol})$ in $\mathrm{MeOH}(2 \mathrm{~mL})$ was treated with acetyl chloride $(20 \mu \mathrm{L})$ for about $10 \mathrm{~h}$, at the end of which time TLC showed the complete consumption of the starting material. The solution was evaporated in vacuo and the residue purified by silica gel column chromatography (EtOAc/petroleum ether, 3:2) to give zeaenol as a white powder (24.6 mg, 91\%). $[\alpha]_{\mathrm{D}}^{25}$ $=-95(c=0.42, \mathrm{MeOH}) .{ }^{1} \mathrm{H}$ NMR $\left(400 \mathrm{MHz}, \mathrm{CDCl}_{3}\right): \delta=11.85$ $(\mathrm{s}, 1 \mathrm{H}), 7.11(\mathrm{~d}, J=15.6 \mathrm{~Hz}, 1 \mathrm{H}), 6.43(\mathrm{~d}, J=2.4 \mathrm{~Hz}, 1 \mathrm{H}), 6.39$ $(\mathrm{d}, J=2.4 \mathrm{~Hz}, 1 \mathrm{H}), 6.00-5.95(\mathrm{~m}, 1 \mathrm{H}), 5.86-5.80(\mathrm{~m}, 1 \mathrm{H}), 5.74$ $5.70(\mathrm{~m}, 1 \mathrm{H}), 5.34-5.30(\mathrm{~m}, 1 \mathrm{H}), 4.27(\mathrm{~m}, 1 \mathrm{H}), 3.98(\mathrm{~m}, 1 \mathrm{H})$, 3.81 (s, 3 H), 3.61-3.58 (m, $1 \mathrm{H}), 2.60$ (br., $3 \mathrm{H}), 2.55-2.24(\mathrm{~m}, 4$ $\mathrm{H}), 1.46(\mathrm{~d}, J=6.0 \mathrm{~Hz}, 3 \mathrm{H}) \mathrm{ppm} .{ }^{13} \mathrm{C} \mathrm{NMR}\left(100 \mathrm{MHz}, \mathrm{CDCl}_{3}\right)$ : $\delta=171.34,165.41,164.16,142.99,133.82,131.74,129.29,128.60$, $107.72,104.04,100.22,73.27,71.55,55.50,37.96,36.11,19.77 \mathrm{ppm}$. IR: $\tilde{v}=3442,2932,2851,1696,1597 \mathrm{~cm}^{-1}$. HRMS (ESI): calcd. for $\mathrm{C}_{19} \mathrm{H}_{24} \mathrm{O}_{7} \mathrm{Na}[\mathrm{M}+\mathrm{Na}]^{+}$387.1420; found 387.1399.

Supporting Information (see footnote on the first page of this article): ${ }^{1} \mathrm{H}$ and ${ }^{13} \mathrm{C}$ NMR spectra for all new compounds and $\mathrm{H}-\mathrm{H}$ COSY for cochliomycin B and zeaenol.

\section{Acknowledgments}

This work was supported in part by the National Basic Research Program of China (grant number 2012CB822101), the National Innovative Drug Fundation (project number 2012ZX09502001), and the National Natural Science Foundation of China (NSFC) (NSF of China; projects numbers 21072217 and 21232002).
[1] P. Delmotte, J. Delmotte-Plaquee, Nature 1953, 171, 344-344.

[2] M. Stob, R. S. Baldwin, J. Tuite, F. N. Andrews, K. G. Gillette, Nature 1962, 196, 1318

[3] G. A. Ellestad, F. M. Lovell, N. A. Perkinson, R. T. Hargreaves, W. J. McGahren, J. Org. Chem. 1978, 43, 2339-2343.

[4] M. S. R. Nair, S. T. Carey, Tetrahedron Lett. 1980, 21, 20112012.

[5] S. V. Sharma, T. Agatsuma, H. Nakano, Oncogene 1998, 16, 2639-2645.

[6] W. T. Shier, A. C. Shier, W. Xie, C. J. Mirocha, Toxicon 2001 , 39, 1435-1438.

[7] M. Isaka, A. Yangchum, S. Intamas, K. Kocharin, E. B. G. Jones, P. Kongsaeree, S. Prabpai, Tetrahedron 2009, 65, 43964403.

[8] M. Isaka, C. Suyarnsestakorn, M. Tanticharoen, P. Kongsaeree, Y. Thebtaranonth, J. Org. Chem. 2002, 67, 1561-1566.

[9] a) E. Moulin, S. Barluenga, F. Totzke, N. Winssinger, Chem. Eur. J. 2006, 12, 8819-8834; b) G. Karthikeyan, C. Zambaldo, S. Barluenga, V. Zoete, M. Karplus, N. Winssinger, Chem. Eur. J. 2012, 18, 8978-8986.

[10] S. Barluenga, P. Dakas, Y. Ferandin, L. Meijer, N. Winssinger, Angew. Chem. 2006, 118, 4055; Angew. Chem. Int. Ed. 2006, $45,3951-3954$.

[11] J. Ninomiya-Tsuji, T. Kajino, K. Ono, T. Ohtomo, M. Matsumoto, M. Shiina, M. Mihara, M. Tsuchiya, K. Matsumoto, J. Biol. Chem. 2003, 278, 18485-18490.

[12] a) H. Tanaka, K. Nishida, K. Sugita, T. Yoshioka, J. Cancer Res. 1999, 90, 1139-1145; b) R. Camacho, M. J. Staruch, C. DaSilva, S. Koprak, T. Sewell, G. Sali-turo, F. J. Dumont, Immunopharmacology 1999, 44, 255-265.

[13] V. Hellwig, A. Mayer-Bartschmid, H. Mueller, G. Greif, G. Kleymann, W. Zitzmann, H. V. Tichy, M. Stadler, J. Nat. Prod. 2003, 66, 829-837.

[14] S. M. Roe, C. Prodromou, R. O'Brien, J. E. Ladbury, P. W. Piper, L. H. Pearl, J. Med. Chem. 1999, 42, 260-266.

[15] P. Dakas, R. Jogireddy, G. Valot, S. Barluenga, N. Winssinger, Chem. Eur. J. 2009, 15, 11490-11497.

[16] C. L. Shao, H. X. Wu, C. Y. Wang, Q. A. Liu, Y. Xu, M. Y. Wei, P. Y. Qian, Y. C. Gu, C. J. Zheng, Z. G. She, Y. C. Lin, J. Nat. Prod. 2011, 74, 629-633.

[17] N. Jana, S. Nanda, Eur. J. Org. Chem. 2012, 4313-4320.

[18] N. Jana, D. Das, S. Nanda, Tetrahedron 2013, 69, 2900-2908.

[19] a) E. J. Corey, K. C. Nicolaou, J. Am. Chem. Soc. 1974, 96, 5614-5616; b) H. Miyatake-Ondozabal, A. G. M. Barret, Org. Lett. 2010, 12, 5573-5575; c) C. Napolitano, P. McArdle, P. V. Murphy, J. Org. Chem. 2010, 75, 7404-7407; d) R. Jogireddy, P. Dakas, G. Valot, S. Barluenga, N. Winssinger, Chem. Eur. J. 2009, 15, 11498-11506; e) P. Dakas, S. Barluenga, F. Totzke, U. Zirrgiebel, N. Winssinger, Angew. Chem. 2007, 119, 7023; Angew. Chem. Int. Ed. 2007, 46, 6899-6902; f) S. Barluenga, E. Moulin, P. Lopez, N. Winssinger, Chem. Eur. J. 2005, 11, 4935 4952; g) N. Winssinger, S. Barluenga, Chem. Commun. 2007, $22-36 ;$ h) L. J. Baird, M. S. M. Timmer, P. H. Teesdale-Spittle, J. E. Harvey, J. Org. Chem. 2009, 74, 2271-2277; i) P. Srihari, B. Mahankali, K. Rajendraprasad, Tetrahedron Lett. 2012, 53, 56-58.

[20] a) D. Liang, H. Luo, Y. F. Liu, Z. Y. Hao, Y. Wang, C. L. Zhang, Q. J. Zhang, R. Y. Chen, D. Q. Yu, Tetrahedron 2013, 69, 2093-2097; b) M. Altemöller, T. Gehring, J. Cudaj, J. Podlech, H. Goesmann, C. Feldmann, A. Rothenberger, Eur. J. Org. Chem. 2009, 2130-2140; c) M. Altemöller, J. Podlech, D. Fenske, Eur. J. Org. Chem. 2006, 1678-1684.

[21] D. C. Rao, D. K. Reddy, V. Shekhar, Y. Venkateswarlu, Tetrahedron Lett. 2013, 54, 828-829.

[22] R. I. Hollingsworth, J. Org. Chem. 1999, 64, 7633-7634.

[23] J. A. Marshall, K. C. Ellis, Org. Lett. 2003, 5, 1729-1732.

[24] D. Meng, P. Bertinato, A. Balog, D. S. Su, T. Kamenecka, E. J. Sorensen, S. J. Danishefsky, J. Am. Chem. Soc. 1997, 119, 10073-10092. 
[25] C. E. Masse, L. A. Dakin, B. S. Knight, J. S. Panek, J. Org. Chem. 1997, 62, 9335-9338.

[26] a) E. Bettelli, P. Cherubini, P. D'Andrea, P. Passacantilli, G. Pianeateni, Tetrahedron 1998, 54, 6011-6018; b) R. D. Crouch, J. V. Mitten, A. R. Span, Tetrahedron Lett. 1997, 38, 791-794.

[27] K. Takai, K. Nitta, K. Utimoto, J. Am. Chem. Soc. 1986, 108, 7408-7410.

[28] D. K. Mohapatra, D. Bhattasali, M. K. Gurjar, M. I. Khan, K. S. Shashidhara, Eur. J. Org. Chem. 2008, 6213-6224.

[29] D. Martinez-Solorio, K. A. Belmore, M. P. Jennings, J. Org. Chem. 2011, 76, 3898-3908.

[30] F. Calo, J. Richardson, A. G. M. Barrett, Org. Lett. 2009, 11, 4910-4913.

[31] a) A. Fürstner, Angew. Chem. 2000, 112, 3140; Angew. Chem. Int. Ed. 2000, 39, 3012-3043; b) R. H. Grubbs, S. Chang, Tetrahedron 1998, 54, 4413-4450; c) M. Schuster, S. Blechert, Angew.
Chem. 1997, 109, 2124; Angew. Chem. Int. Ed. Engl. 1997, 36, 2036-2056.

[32] a) J. Funel, J. Prunet, J. Org. Chem. 2004, 69, 4555-4558; b) A. Furstner, O. R. Thiel, G. Blanda, Org. Lett. 2000, 2, 37313734; c) P. R. Krishna, M. Narsingam, J. Comb. Chem. 2007, 9, 62-69.

[33] C. S. Poulsen, R. Madsen, J. Org. Chem. 2002, 67, 4441-4449.

[34] M. S. Sanford, J. A. Love, R. H. Grubbs, J. Am. Chem. Soc. 2001, 123, 6543-6554

[35] I. W. Ashworth, I. H. Hillier, D. J. Nelson, J. M. Percy, M. A. Vincent, ACS Catal. 2013, 3, 1929-1939.

[36] B. Schmidt, O. Kunz, M. H. Petersen, J. Org. Chem. 2012, 77, 10897-10906

Received: October 28, 2013

Published Online: January 28, 2014 